causes have been at this work for "ages," by the discovery of a subterranean Roman villa. But what are such floods and deposits as these compared with those of the Nile, Ganges, Mississippi, or Niger? It is. something, however, that $\mathrm{X}$ and the Emperor, ego et rex meus, are now convinced that the late disastrous floods in France and Fngland were simply the effects of rain, as "the flood" was of yore. But when my two illustrious pupils and the "Corresponder.t" attempt to remedy the effects of rain on rivers I recommend them to leave woods out of their consideration. Our respected grandmothers always "babbled" about them.-Your obedient servant,

Grorgig Grahnwood, Colonel.

Brookwood Park, AlRgsford, December 18 th, 1866.

\title{
TITE DEVONIAN ROCKS OF DEVONSHIRE, ETC.
}

To the Editor of the Geocogical Magazine.

SIR.-I do not wish to enter into a controversy on the Devonian delusion; I had rather let my own field work, and that of the Irish branch of H. M's. Geological Survey, speak for itself.

There are, however, some statements in Mr. Salter's letter, in your last number, which might mislead persons if they were allowed to pass without contradiction.

There is no unconformability between any parts of the Old Red Sandstone, either in the south-west of Ireland, or in South Wales.

The unconformability which Mr. Geikie and other of my colleagues have shown to exist in Scotland, between beds that have hitherto been called Old Red Sandstone, is of itself sufficient to prove that that term can only be retained provisionally for those groups till they are more thoroughly distinguished, and some of them freshly named.

In Ireland I adopted the local name of "Dingle beds" for the mass of red rocks that rest in apparent conformity on the Upper Silurian rocks, and are covered quite unconformably by the upper part of the OId Red Sandstone.

It is by no means certain, that these "Dingle beds" appear anywhere in Ireland, except in the Dingle promontory.

To the south of Dingle Bay, there is not the slightest trace of any unconformability in the Old Red Sandstone.

Some years ago I wished to know whether the dying away of the Old Red Sandstone in South Wales, from Herefordshire towards Pembrokeshire, was accompanied by any break in the veins; I examined the whole country, from the neighbourhood of Llandeilofawr and Llandovery, by Brecknock and Abergavenny to Pontypool, but could not detect any direct evidence of unconformability between the top of the Upper Silurian, and the base of the Carboniferous Limestone.

In North Devon I believe it will be possible to trace a boundary between the red rocks of Porlock, Minehead and Dunster, which are genuine Old Red Sandstone, and the grey slates, and variously coloured grits, and slates containing marine fossils above them. 
I do not believe that any geologist will ever be able to trace a boundary in those slates and grits, so as to subdivide them into two clearly marked groups, such as Infracombe, Combe Martin, Marwood, Pilton beds, etc., until that is done by a good stratigraphical geologist, independently of all fossil evidence. That fossil evidence is not worth a rush in this case, because we are merely reasoning in a circle, drawing a boundary to suit the fossil localities, and then using the fossils to prove the correctness of the boundary. According to the results of my field work, (hasty and imperfect enough, doubtless in Devon, but still based upon the experience acquired by thorough and exhaustive work, carried on patiently for years in Ireland), the Old Red Sandstone of Porlock, Minehead and Dunster is brought up again by a great fault in the centre of North Devon, and forms a ridge, running from Morte Bay to Wiveliscombe, the Lynton, Combe Martin and Ilfracombe beds being part of the Marwood and Barnstaple beds.

If I am mistaken in this, then the central red ridge from Morte Bay to Wiveliscombe is different from anything we have in Ireland, and can be used to divide the grey slates of North Devon into an Upper and Lower group, still having the genuine Old Red Sandstone of Porlock, Minehead, and Dunster below them all, and the Coalmeasures conformably above them all.

These Devonian rocks will then rest, like their contemporaries, the Carboniferous Slate in Ireland, between the top of the Old Red and the base of the Coal-measures, and will be the muddy and sandy representatives of the Carboniferous Limestone, with a somewhat different fauna, arising partly from difference of habitat and partly from difference of province. The contemporaneity of different assemblages of fossils in closely adjacent areas, which is the explanation of Barrande's Colonies, has not yet been sufficiently worked out or attended to. It has been the cause, not only of the Devonian delusion, as I have called it above, but of the confusion among the Cambro-Silurian series of Wales and elsewhere.

I, for one, cannot feel any confidence in the stratigraphical groups of these rocks, established merely to suit the supposed horizons of certain fossils, and not worked out by honest stratigraphical obserrations in the field.

Lastly, let me say that I seem to myself to have been endeavouring to fix the exact place of the so-called Deronian system instead of explaining it away. Yours,

Dublns, Jantuary 6th, 1867.

J. Berte Jukhs.

\section{FORM OF THE GROUND AND FAULTS IN THE DRIFT.} To the Editor of the Grocogican Magazing.

SrR,-Allow me to correct a slight error which has crept into print, although not in the proof of my paper, in your January No. At page 9, line 5, for "became " read become, and for "sloping," in line 10 , read slope, when it will be seen that (however ill oxpressed) 